Izvirni znanstveni članek Original scientific paper (1.01) Besedilo prejeto Received: 29. 2. 2020; Sprejeto Accepted: 8. 5. 2020 UDK UDC: 27-789.32:94(497.5)"14/16" DOI: $10.34291 /$ Edinost/75/Patafta (C) 2020 Patafta CC BY 4.0

\title{
Daniel Patafta
}

\section{Croatian Franciscans at the Frontier between Christianity and Islam from the $15^{\text {th }}$ to the $17^{\text {th }}$ Century}

\author{
Hrvaški frančiškani na mejišču krščanstva \\ in islama od 15. do 17. stoletja
}

\begin{abstract}
The conquest of the Ottoman state at the end of the $15^{\text {th }}$ and the beginning of the $16^{\text {th }}$ century put under its rule most of the territory inhabited by Croats. In the Croatian lands that came under Ottoman rule, the legal position of Catholics was built on the model of Muhammad's order towards those who recognized his political power and possessed "holy books and did not accept Islam. The conqueror of Bosnia, Sultan Mehmed II gave the Bosnian Franciscans Hatisherif the so-called Ahdnama, by which he guaranteed to the Franciscans personal inviolability and freedom of religious activity, and to the Christian population unhindered possession of property and freedom of residence in the area of his authority. It was a pragmatic act, because despite the legal guarantees, the position of Catholics and Franciscans was very difficult. Wars with Christian, mostly Catholic countries, often provoked terrible retaliation. The Franciscans were the only Catholic priests in the area under Ottoman rule. Although they often suffered great injustices from state and local Ottoman powerful people and resisted the proselytizing efforts of Orthodox bishops, they expanded their activities beyond the borders of medieval Bosnia. The missionary dynamics and tradition of the Franciscans over the centuries have made the Franciscans in Croatian lands a vital component of the Order and they, in the service of preserving Catholicism and pastoral work, successfully maneuvered between the demands of the Ottoman theocratic state, Orthodox proselytism and the demands of Christian states of Western Europe, mainly of the Habsburg Empire, the papacy, and Venice.
\end{abstract}

Key Words: Franciscans, Bosnia Argentina, Slavonia, Danube region, Islam, Ottoman Empire, theocracy

Izvleček: Osvajanje osmanske države konec 15. in v začetku 16. stoletja je pod svojo oblast vzelo večino ozemlja, naseljenega s Hrvati. Vhrvaških deželah, ki so spadale pod osmansko oblast, je bil pravni položaj katoličanov zgrajen po vzoru Mohamedove ureditve tistih, ki so spoštovali njegovo politično moč, imeli "svete knjige in niso sprejemali islama. Osvajalec Bosne, sultan Mehmed II., je bosanskim frančiškanom Hatišerifom podal tako imenovano Ahdnama, sčimer jim je zagotovil osebno nedotakljivost in svobodo verske dejavnosti ter krščanskemu prebivalstvu neovirano posedovanje lastnine in svobodo bivanja v območju njegove oblasti. Šlo je za pragmatično dejanje, saj je bil položaj katoličanov in frančiškanov 
kljub zakonskim jamstvom zelo težaven. Vojne s krščanskimi, večinoma katoliškimi državami so pogosto izzvale strašno maščevanje. Pod osmansko oblastjo so bili frančiškani edini katoliški duhovniki na njihovem območju. Čeprav so pogosto trpeli velike krivice državnih in lokalnih otomanskih oblastnikov in se uprli prozelitskim prizadevanjem pravoslavnih škofov, so svojo dejavnost razširili tudi zunaj meja srednjeveške Bosne. Z misijonsko dinamiko in tradicijo frančiškanov skozi stoletja so frančiškani v hrvaških deželah postali življenjsko pomemben sestavni del Reda, ki je v službi ohranjanja katolicizma in pastoralnega dela uspešno manevriral med zahtevami osmanske teokratske države, pravoslavnim prozelitizmom in zahtevami krščanskih držav zahodne Evrope, predvsem habsburškega cesarstva, papeštva in Benetk.

Ključne besede: frančiškani, Bosna Argentina, Slavonija, Podonavje, islam, Otomansko cesarstvo, teokracija

\section{Introduction}

Missionary mobility of the Franciscans, which was also incorporated into the Rule of Saint Francis, assumed contact with Islam from the very beginning of the Order. From their arrival to the territory now known as Croatia in the Middle Ages, the Franciscans became very involved in the missions of the Church in Bosnia, where they successfully spread Catholicism among Bosnian Christians for two centuries and made Bosnia a Catholic country with a Catholic ruler. Their mission also included contact with the Orthodox on the eastern border of the Bosnian Kingdom, and with the Hussites in the region of Srem and Bačka. As the Ottomans invaded Southeast Europe throughout the $15^{\text {th }}$ and $16^{\text {th }}$ centuries, Islam was no longer the reality of the Church only in the then relatively remote Middle East, but came to the very borders of Western Christianity. A series of historical events that followed - in 1463, the Bosnian Kingdom disappeared, and the remains of Dušan's Serbian Empire were gradually disappearing as well, the Battle of Krbava in 1493 and Mohács in 1526 made Islam a permanent factor in the life of Central and Southeast Europe. The former Croatian Kingdom, reduced to »bits and pieces«, became the frontier between Islam and Christianity. With the spread of Ottoman rule to Slavonia, the Danube and Dalmatia, Franciscans from these areas joined the Province of Bosna Srebrena as the only Catholic clergy on the European territory of the Ottoman Empire. Their mission continued over the next two centuries and consisted of preserving Catholicism in the area that was facing the challenges of Islamization and aggressive Orthodoxy, persecution and diplomatic maneuvering with the Ottoman authorities. This presentation will demonstrate how the Franciscans in Slavonia and the Danube region, which inevitably means collision with the present-day 
Bosnia, lived and acted during the Ottoman rule, and what their relationship to Islam and the theocratic Ottoman state was like. In other words, the ultimate goal is to analyse the relationship that the Franciscans had with Islam in a region where the interests of the Catholic Habsburgs, the papacy and the Catholic states of the Christian West were intertwined with the interests of the Ottoman Islamic State. During the period before and after the Great Vienna War, the Franciscans were the main and only link between Catholics in the Ottoman Empire and Western Christian States. That is to say, they were the core starting point and the bridge that linked Christianity and Islam for over two long centuries. In this context, it is certainly important to note the perception of Islam by Christianity in the West and by the Franciscans who were continually instructed to coexist with Islam and representatives of the Ottoman theocracy. This paper will deal with the work of the Franciscans from the Battle of Mohács in 1526 to the Peace treaty in Sremski Karlovci in 1699, on the territory of Croatian countries, with particular emphasis on the territory of Slavonia and the Danube region.

\section{Franciscans and Islam until the fall of the Bosnian Kingdom in 1463}

The rapid rise and global spread of Islam among Christians of the time, directly targeted by Muslim weapons or discriminatory legislation in the Iberian Peninsula, North Africa and the Middle East, caused fear and disbelief at what at the time seemed as the breakdown of Christian world and the arrival of something new, unknown, foreign, and simultaneously pagan and barbaric. But religion was not the only thing being threatened; the whole Christian world was endangered in all its aspects. The Byzantines, who saw themselves as heirs to the Greek and Roman culture and guardians of the ancient civilization, viewed the Islamic expansion as an invasion of "primitive Arabs«, barbarians who threatened not only Christianity but civilization in general. (Hourani 1996, 9-10; Hitti 1988, 114-214; Kursar 2003, 133-136) In the $11^{\text {th }}$ century, Islam remained the only opponent of Western Europe. Centuries of localized warfare along the borders gradually grew into a collective European war against Muslims. The Europeans joined the Spaniards in Reconquista, the Normans went to southern Italy and Sicily to fight Islam, and a bit later, the first armies 
of Crusaders arrived in the Middle East: Roger I of Hauteeville began the Reconquista in Sicily in 1060, Alfonso VI entered Toledo in 1085, and Geoffrey of Bouillon conquered Jerusalem in 1099. The mutual struggle of the European states against the main enemy of Christianity - Islam, became one of the foundations for the ideological unification of Europe led by the Pope. (Rodinson 2002, 4-6) The initiation of the Crusades was linked to the agitation of religious sentiment in Western Europe, which was contributed by various reform movements within the Church. The Benedictine monastic movement from Cluny was particularly prominent, overshadowing the disunity of European states and significantly contributing to the creation and rise of the papal supreme power. (Rodinson 2002, 4-6; Franzen 1988, 165)

Bernard of Clairvaux (1090-1153), one of the most notable polemicists on the topic of the Crusades, a proponent and preacher of the Second Crusade, which was initiated by his disciple Pope Eugen III (11451153), propagated the motive of Islam as God's punishment for the sins of Christians. Bernard fully turned to eschatological interpretations, and viewed Muslims as the weapons of Satan, who proved to be a rather serious enemy of Christ. He shared a trait with a large number of anti-Turkish polemicists that came afterwards - on the one hand, he felt strong love for God and Christians, while on the other, he clearly despised Islam and Muslims. (Marković 1995, 73-86)

Paradoxically, the first person to point out the spiritual kinship of Christianity and Islam was Pope Gregory VII, who provided not only a theological basis for the development of the idea of the Crusades, but also the first call for a crusade. In 1076, Gregory VII sent a letter to the Algerian prince al-Nasir. The tone of the letter was certainly conditioned by practical goals such as the protection of the Christian community, the interests Roman merchants had for the trade with Bongie harbour (Bijaya) under al-Nassir's sovereignty, etc., but still reveals an awareness of the spiritual union of the two religious communities: "There is a kindness which we owe to one another more than to other nations, for we know and profess one and only God, though in different ways, glorifying and worshipping Him every day as the creator and ruler of the world." (Kursar 2003, 146) 
This papal call for peaceful relations between Christians and Muslims is visible throughout the Middle Ages only in the work of St. Francis of Assisi (1181-1226), who, despite considering the Muslims as unbelievers, advocated that their conversion be achieved through peaceful missionary service, through dialogue rather than strife or sword, as was customary in his day. During the Fifth Crusade, he protested against violence by undertaking a "peaceful march". In 1219, he arrived in Syria, Palestine and Egypt, and stayed for a year and a half, trying to negotiate peace between the Sultan Malik al-Kamil and the Crusaders. (1Cel 1995, Cap. XX, \$55-56; CAss [CA], 1995, \30; 2Cel 1995, Cap. IV, \$617; LegM [LM] 1995, Cap. IX, \$1171) The Sultan and some of the Christian knights agreed to a ceasefire, thanks to the advocacy of the papal legate Pelagius, but a conflict arose and the battle took place at Damietta (Baltim). Although he tried to convert the Sultan himself to Christianity, Francis of Assisi gained sympathy from Muslims for his peacekeeping efforts. This is confirmed by the independent eyewitness of all these events, Bishop Jacques de Vitry. (2Vitry 1995, \$2210-2213) Pope Gregory VII's letter to Prince al-Nasir was fully valorised in the Christian world only in 1965, at the Second Vatican Council, in the Nostra aetate declaration on the relation of the Catholic Church to non-Christian religions, which recognized the right to possess the Revelation. Sources tell us that Francis came out of the meeting enriched by the experience of others. He moved on from his original desire for martyrdom, not advising the Rule of Martyrdom as an ideal, but spiritual behaviour in proclamation.

From the earliest times, activity among the Saracens and other non-Christians was firmly integrated into the Franciscan conception of religious life. This is evident in the process of institutional maturation as the idea of active life through a mission receives its normative confirmation first with the Regula non bullata (1221) and then with the Regula bullata (1223). The Regula non bullata and its Chapter XVI, mirroring the earliest life practices of Francis' followers, enables the brethren to go »among the Saracens and other non-believers", if the Provincial Minister agrees to it: "If any brother wishes, by divine inspiration, to go among the Saracens and other non-believers, they may go with the permission of their minister and servant." (Francis of Assisi 2012, 169-170) The Regula bullata regulates missions among the Saracens with its chapter XII: "Whoever should, by divine inspiration, wish to go among the Saracens and other infidels 
must ask permission from their provincial ministers. The ministers should grant permission only to those whom they consider qualified to be sent." (Francis of Assisi 2012, 195) As the process of institutionalization took place with the support and cooperation of the Pontifical Curia, which is especially evident in the making of the Regula bullata (Melville 2016, 215), it is clear that the Pope saw a potential for an adequate itinerant proclamation of the Gospel in the emerging Order. In other words, such an option for practising religious life was supported by the Pope from the beginning. In line with that, the inclusion of the mission "among Saracens and other non-believers in the core normative document, supported by the Pope, allowed the new Order to further profile itself within the broader framework of the Church, and position itself as one of the champions of active Christianization. Another important implication touched on the mere understanding of monastic life, that is, the understanding of the Order's identity. Institutionalizing the possibility of missionary activity among the Saracens, which fit into the broader concept of itinerant preaching practised in the early days of the fraternity (Esser 1983, 44-48), represented a significant conceptual departure from the then Benedictine type of monasticism, as well as the restored eremitic monasticism that became common among the regular canons in the $11^{\text {th }}$ century.

In the context of the transformation of the fraternity into a true ecclesiastical order, a model of monastic life was formed, necessarily combining the active preaching of the Franciscans with the "more classical monastic model of practising vita religiosa. Because, as one of the leading Franciscan scientists, Cajetan Esser, states, in order to preserve the cohesion of the growing community, it was necessary »to connect the original ideal of itinerant preaching with the brothers' need for a permanent residence $(1983,114)$. In that process, the normative confirmation of the possibility of going on a mission among the Saracens became a medium for the transfer of that early religious attribute onto the next Franciscan generations, as well as an official justification for missionary mobility, which was directed towards the Holy Land and occurred more or less continuously in the following periods, during the $13^{\text {th }}$ and $14^{\text {th }}$ centuries.

The development of a monastic practice combining the typical monastic way of life with the life of the travelling missionaries is also reflected in the East, which the Franciscans visited more or less regularly during the $13^{\text {th }}$ 
century, building houses for members of the Order or pilgrims - establishing a house in Jerusalem (1229), smaller institutions for the reception of pilgrims in Bethlehem and Nazareth, and houses along the coast of Antioch, Tripoli, Beirut, Tire and Sidon, Akon and Jaffa (the latter was erected and luxuriously furnished by /Saint/ King Louis IX in 1252/1253) and also on the outskirts of Nicosia in 1232 , and during the $13^{\text {th }}$ century in Paphos, Limassol, Famagusta (whose reputation especially grew in the late $13^{\text {th }}$ and early $14^{\text {th }}$ centuries) (Jerković 2019, 189; Patafta 2018, 116; Waddingus 1932, 222; Waddingus 1933, 405). The normative backdrop was then a stable backbone on which every mission to the East was based, to the area that is especially attractive to itinerant preachers, as well as the medieval people in general, as it represents the possibility of coming close and returning to the main source and origin of Christianity. Also, in the context of missionary departures and the spread of the Franciscans to the East, a territorial-administrative organization was being developed. Missionary mobility was a necessary precondition for practising and restoring the basic features of the Order, though it also contributed to a different understanding of monastic life from the very beginnings of the Franciscan Order.

Upon the arrival of Muslim armies of the "Arab Caliphate« in the Middle Ages, all Muslims were identified as the Saracens, regardless of ethnicity. A similar thing happened at the threshold of the new age, when the "Turkish" Ottoman Empire invaded Europe: they inherited the name Saracens, even though it did not correspond at all to the reality of that multi-ethnic empire. The Ottoman Sultan was officially the sole administrator and ruler of the empire, although the first Ottoman rulers bore the title of bey, thereby acknowledging the sovereignty of the Seljuk Sultanate. Murat I was the first Ottoman to hold the title of sultan, i. e. emperor or king. (Kursar 2013, 389; Hammer 1979, 57-188) With the fall of Constantinople in 1453, the state largely embarked on the path of becoming a powerful empire, so Mehmed the Conqueror truly became its first true emperor, that is, its padishah. From 1517, the Ottoman Sultan was at the same time also the Caliph of Islam, so the Ottoman Empire was in fact the caliphate, that is, the Islamic religious state until its dissolution in 1922 (i. e. until the abolition of the caliphate in 1924). The Ottoman Empire was, in fact, a large military organization, only interested in new conquests and 
tax collection, while its administrative system was designed to provide manpower for the army and money to pay for it.

\section{The Ottoman invasion of Croatian lands and the legal position of Catholics}

Three events dating back to the end of the Middle Ages are of particular importance when it comes to the history of Franciscanism in Croatian territories: the fall of Bosnia in 1463, the division of the Vicariate of Bosnia in 1514, and the defeat of the Christian army near Mohács in 1526.

The new period in the Franciscan activity in the Croatian lands was primarily related to the missionary work of the Croatian Franciscans in Bosnia. Their missionary work had to be confirmed with authentic Franciscan life, so the supreme ecclesiastical authorities decided that the Franciscans who are active in Bosnia should establish a separate Franciscan province, dependent on the general of the order, the so-called Vicariate. Therefore, Pope Benedict XII sent the Minister General of the Franciscan Order Gerard Odonis to visit the Hungarian-Croatian King Charles Robert, and then Bosnian ban Stjepan Kotromanić. Gerard founded the Vicariate of Bosnia in 1340 and appointed his companion Peregrine Saxon as its vicar. Saxon was also the bishop of Bosnia from 1349 to $1356 .{ }^{1}$ The Vicariate of Bosnia brought together Franciscan missionaries of different nationalities, though the burden of missionary work belonged to the Croatian Friars. Due to the success of their activities, all missionaries aspired to an authentic Franciscan life in explicit poverty and apostolic activity. The work of the vicarage was also supported by ban Stjepan Kotromanić, who asked the Pope in 1347 to allow the Bosnian vicar to establish friaries in places where Franciscans or other monks do not have houses. (Mandić 1968, 59-227) During the service of Vicar Bartol of Alvernia (1366-1408) of almost four decades, the Vicariate of Bosnia expanded its presence and activity beyond the borders of medieval Bosnia. First in 1369, Pope Urban $\mathrm{V}$ allowed the vicariate members to collect and receive alms in Croatia

1 Archives of the Croatian Academy of Sciences and Arts (hereinafter: AHAZU), Eusebius Fermendžin, Acta Croatiae, rkp, sign. XV / 24/16, 349-353. 
and Hungary (Fermendžin 1892, 36), then Gregory XI (1370-1377) allowed them to build eleven friaries outside Bosnia in 1372 (Fermendžin 1892, 38). In the $14^{\text {th }}$ century, Bartol of Alvernia built the Bosnian vicarage as the first Franciscan administrative unit to return to the strict obedience to the Franciscan rule - observance. Its emergence and spread coincides with the general ecclesiastical efforts around church restoration following the Pope's stay in Avignon and during the so-called Western schism (1378-1414).

When the Ottomans crossed the Bosporus in 1352, the Franciscans were already well established in the Croatian territories and gathered around two powerful provinces: St. Jerome in the coastal area and the Vicariate of Holy Cross in Bosnia. Both provinces had played an extremely important role in the evangelization and spread of the Catholic faith among Bosnian Christians, Hussites in the area of Srem, Banat and Bačka, as well as among the Orthodox in the area along the Hungarian-Croatian and Bosnian borders in the previous century. Their friaries were located on a rather wide area from Puglia, across the Danube, to the Black Sea. (Eubel 1898, 599-602) Pope Boniface IX mentions in the Bull Ex iniuncto from 1402 that the Franciscans converted to Catholicism some 50,000 Bosnian Christians in that Vicariate (Mandić 1968, 76; Eubel 1904, 140).

The fall of Bosnia put the Catholic population and its clergy again in a difficult position. Though, in 1463, the guardian of the Bosnian Custody, Br. Anđeo Zvizdović managed to get a special charter, known as Ahidnâme, from Sultan Mehmed II, which guaranteed the Franciscans personal inviolability and freedom of religious activity. Also, the Catholic population was given the freedom to possess property and reside in the area of his authority. Despite legal guarantees, the position of Catholics and Franciscans in Bosnia was difficult. The situation especially deteriorated during the wars with Christian armies, which caused retaliation by the Ottomans and the expulsion of the Catholic population from Bosnia.

The province of Bosna Argentina, located within the Ottoman Empire, suffered great devastation during the Ottoman conquests, with some friaries completely ravaged and consequently abandoned (Konjic 1524, Zvornik 1533). Nevertheless, a relatively large number of friaries remained functional until the end of the $17^{\text {th }}$ century: Hvojnic/Fojnica, Kreševo, Visoko, 
Sutiska, Modrića, Srebrenica, Olovo, Gradovrh (Gornja Tuzla), Soli (Donja Tuzla) and Rama (Gonzagae 1587, 583-589). The Franciscans under the Ottoman rule shared the common destiny of the people living there miserable exile, displacement and tribulations of war. In 1578, Minister General of the Franciscan Order Francis Gonzaga wrote that it was almost impossible to list all the troubles and injustices suffered by the brothers of the Bosnian Province $(1578,586)$.

Despite the extremely difficult position of Catholics in Bosnia, the Franciscans extended their activities to parts of Dalmatia, Slavonia, southern Hungary and Bulgaria. As the secular clergy disappeared in these areas, they had to accept the responsibility of pastoral activity as they already did in Bosnia. Organizationally tied to the remaining friaries in Slavonia and Bosnia, they assumed the role of pastoral workers in a wide area from Budim to the Adriatic, in the north and south, and from Bulgaria and Timisoara to the borders of the Croatian Kingdom, in the east and west. In the area of Ottoman Slavonia and Srem, Franciscan communities remained in charge of the pastoral care of Catholics in the area, but some Bosnian friaries also took over pastoral care for Catholics north of the river Sava. For example, the friary in Visoki cared for the parishes in the upper Posavina (Gradiška and Orubica), the friary in Modriča was responsible for the parish Rastić-Sikirevci, Gradovrh for the parishes in Bačka, Srebrenica for those in Banat, and Sutiska for the ones in Baranja. Olovo took care of almost all parishes in eastern Slavonia and in Srem, but also some in Baranja, Bačka and Banat. (Fermendžin 1892, 366-371, 377, 483, 492-498; Draganović 1883, 1-48; 1934, 65-78; Buturac 1970, 169-177; Hoško 2000, 29-30)

The position of the Catholics in the Ottoman Bosnia (present-day Bosnia and Herzegovina), as well in the Turkish Croatia (Croatian territories under Ottoman rule, Dalmatia, Lika, Slavonia, Srem), was based on the Ahidnâme issued by Mehmed the Conqueror to the Bosnian Franciscans in Milodraž after or during the conquest of Bosnia on May 28, probably 1463 (the date states the day and the month, but not the year of its publication) (Vladimirović 1775, 26; Lastrić 1786, 114-115; Fabianich 1884, 41-42). During the dissolution of the Bosnian state and the king's defeat, Fr. Anđeo Zvizdović, a custos of the Franciscan Bosnian Custody, faced the victorious Sultan in Milodraž, one of the three most important centres 
of the Bosnian Kingdom, next to Sutjeska, where the Bosnian throne was located, and Mile near Visoki, where assemblies were held. Given the option to choose between a suicide clash with an invincible Ottoman ruler, who after conquering Constantinople also dreamt of world hegemony and conquest of Rome (which was prevented by his death), and reconciliation with his destiny and recognition of the Ottoman rule, thereby preservation of Catholicism in Bosnia and neighbouring countries, Fr. Anđeo chose the latter. Thanks to his choice, the sultan guaranteed the Franciscans, and consequently their flock, basic rights reserved for his subjects. Thanks to the Ahidnâme, the Bosnian Franciscans became the only representatives of the Catholic Church in Ottoman Bosnia and Turkish Croatia with a legally regulated position.

The constant conflicts between the Christian rulers and the Ottomans impeded normal work and communication within the Vicariate of Bosnia, making work difficult for the Franciscans, who were constantly under suspicion of the Ottoman authorities. After the fall of Srebrenica in 1512, the Vicariate of Bosnia was divided into two parts: Vicaria Bosnae Croatiae with friaries in Croatia, under Christian rule, and Vicaria Bosnae Argentinae in the Ottoman territory. (Fermendžin 1892, 307; Mandić 1968, 148-149)

The Catholic Church on the Ottoman territory did not have a clearly regulated status, probably due to the fact that its religious leader, the Pope, had long been the Sultan's main nemesis and the main initiator of anti-Ottoman crusades. The Orthodox Church, on the other hand, had enjoyed the official recognition of the Ottoman administration of the highest level since 1454, a year after the conquest of Constantinople, when Mehmed II The Conqueror appointed Gennadios Scholarios, the sworn enemy of the union of the Orthodox Church with Rome, and therefore a suitable candidate, for the patriarch of the Ecumenical Patriarchate of Constantinople. In 1557 , the Serbian Orthodox Church was similarly restored and officially recognized, while Makarije Sokolović, probably a close relative of the then-third vizier, and latter a grand vizier, the mighty Sokollu Mehmed Pasha, was appointed patriarch. (Fedalto 2008, 210-215; Malcolm 2011, 113-114)

The sultan's contracts with Catholics were not concluded at the level of the Empire, but individually, through separate agreements with different 
Catholic communities in different parts of the Ottoman state. Catholic groups would receive so-called letters of guarantee or guarantees of security entitled aman, guaranteeing them the security of life and property and religious freedom. Aman would then become ahd or contract, i. e. Ahidnâme, the imperial letter of guarantee. The same name was used for the letters of guarantee for non-Muslims from foreign countries (darü'lharb, or »house of war") who came to Islamic countries as merchants, pilgrims, or diplomats. (Schacht 1986, 429-430) Ahidnâme was also the name for interstate treaties with Western European states, largely of commercial character, and peace treaties. That mirrored the kind of »foreignness" felt by the native Catholics, also reflected in their Ottoman names: Terms Frank, Ifrend ž, and Latin originally signified peoples on the other side of the Mediterranean, beyond the borders of the Ottoman Empire, referring to the French, Italian, and inhabitant of the western Mediterranean, and Western Europeans in general addition to Catholics, Ahidnâme were also sometimes issued to Orthodox Christians and members of the Armenian Church in Jerusalem. After receiving the Ahidnâme, the non-Muslim native population was granted the status of zimi, or Islamic State subjects who enjoyed some fundamental rights, such as personal freedom and security, security of property, as well as religious rights within the limitations posed by the Sharia law. (Zirojević 1980, 375-385)

Not only did Bosna Argentina recover quickly from the initial impact, but it started to expand in territorial terms, following the changes in the Ottoman border in the north. That was the way the Bosnian Franciscans reached Slavonia, Hungary, Transylvania, Banat, Serbia, and even Hungary. The Franciscans often followed or led the migration of the Catholic population from Bosnia to the north. (Pavich 1766, 42) They established new parishes on the new territory, which was certainly facilitated by the general shortage of Catholic clergy in Hungary. The Franciscan missions, and especially the missionary activities among the Protestants and Orthodox, were very successful. Also, the mission of the Bosnian Franciscans in Bulgaria under the leadership of Fr. Peter Soljanin (Zlojutrić) was a great success, and soon four friaries and parishes were established there. In 1622, a separate Franciscan Custody was established as well. (Dujčev 1935, 14-23; Tocanel 1972, 239-240) 
Such activity of the Bosnian Franciscans and their "CO-ordination" with the Ottomans was also immortalized in the phrase "Wherever the Turks and their hordes go, friars with bags follow «. The new territorial scope was self-consciously emphasized by the Franciscans themselves. Bosnian Bishop Fr. Franjo Baličević wrote that Bosna Argentina which he called Il Regno di Bosnia ("Bosnian Kingdom") was located between Macedonia, Carinthia and Styria, and the Adriatic Sea. (Gavran 2007, 61) In 1693, the Provincial Minister, Gabrijel Stanić of Baška sent a letter to the Pope noting that the borders of Bosna Argentina stretch from the Adriatic Sea to the "Tartaria" (a mari Adriatico ad fines Tartarie). (Lastrić 1786, 66)

\section{Franciscans and 0ttomans - Coexistence under 0ttoman rule}

Publicly expressing and practising Christianity in the vicinity of Muslims was prohibited by the Sharia law. Based on a report by the Bosnian bishop Nikola Ogramić-Olovčić from 1672 Sarajevo, it can be concluded that the public holding of religious services was prohibited in that city. The Bishop's report from Banja Luka from that same year states that there was no church in the city, "and that it was forbidden to celebrate holidays and to hold masses on holidays, so for that reason they refrained from praying, listening to masses, performing processions, and all our other Christian customs (Jelenić 1918, 135). Ogramić-Olovčić, on the other hand, stated that the situation of Catholics in Požega was much better than in other parts of the Empire, despite having to pay for liturgical services, because the bells were allowed to ring. The reason behind this extraordinary privilege, the use of bells, may stem from the fact that the Catholic population of Požega enjoyed a privileged position and performed certain military duties, and that a group of very wealthy merchants who financed the Church lived in the city. Catholics were the only officially recognized Christian denomination in the city, while Orthodox and Protestants were not allowed to settle in the area. (Jelenić 1918, 144-145)

Požega Catholics living isolated from the Muslims in their mahalle might also have been the reason why the use of the bells was allowed. On the other hand, in places where Muslims and Christians lived together, the use of bells or the sounds of the so-called nakus, serving as a Christian call to prayer, was strictly prohibited. In 1623 and 1682, the Fojnica Friars 
had to justify themselves, as they were accused of using bells, which they denied and claimed false. However, Benić mentions that in the last quarter of the $18^{\text {th }}$ century, the Sutjeska friary acquired a bell, despite the ban on ringing. Whether the bell indeed rang or not, we cannot really say at the moment. $(2003,24)$ Usually, instead of using bells, the Ottoman Bosnian Catholics were called to prayer in the same way as it was done in the Middle East, using the nakus, metal plates that would be hit with a hammer.

The introduction of the Jules tax in the $17^{\text {th }}$ century hit the churches and friaries hard, and the situation was exacerbated by the outbreak of the war in 1683. Most Franciscan friaries in Bosnia were in debt and unable to reopen their doors after the war. Benić also mentions the Province's attempt to find a way out of debt in 1679 , when 16 friars were sent to various Catholic countries in Europe to collect alms for the purchase of pawned convent items. A rather large amount of financial aid was raised for the Bosnian friaries, but due to the outbreak of the war, the mentioned sixteen never returned to Bosnia and never brought the charity collected. (Benić 2003, 34-36) Even during the $18^{\text {th }}$ century, the Jules remained the greatest tax that the Franciscans had to pay, and the fact that it had to be paid upon arrival of each new vizier who changed rather quickly in the $18^{\text {th }}$ century, made their lives even more difficult.

Apart from the two periods of general conflict during the conquest of Bosnia, and the wars in the second half of the $17^{\text {th }}$ century, the conflicts of lesser intensity during which the native Christian population worked alongside the enemies in Bosnia were quite numerous. Collaboration with the enemy and sometimes the accusation itself inevitably resulted in Ottoman retaliation. Particularly critical were the periods during the wars with Hungary in the first half of the reign of Suleiman the Magnificent, from 1520 to 1540, and the Long War with the Habsburgs (1593-1606). Franciscan chroniclers report that in 1524 the Ottomans overthrew the friaries of Konjic, Visoko, Sutjeska, Kreševo and Fojnica, and arrested their guardians. The friary in Konjic was never built again, while other friaries were rebuilt by 1566, »if not earlier«, as Lastrić described it. (Lastrić 1786, 55-56) In 1538, the friary in Zvornik was confiscated by the authorities. Despite these obvious examples of repression that the Franciscans accused of treason were facing, the authorities had not yet completely abolished the protection of the Church, as evidenced, among other things, 
by the arrest of the Haramis who killed the Friars of the friary in Rama in 1532. (Kemura 1916, 22) In 1563, the Ottomans demolished the friaries in Mostar and Ljubuški because the Franciscans had helped Bishop Daniel Vocensis, accused of treason and espionage, to escape. The determination of the authorities to prevent the clergy from cooperating with the enemy is evident in the provisions of the Bosnian Sanjak Kanun of 1516, 1530 and 1542, which anticipated severe penalties for those "non-believers and priests in churches who inquire about the situation and provide information to the non-believing lands«. In 1600, due to the uprising of Catholics in Slavonia, including the Franciscans, the Pasha of Požega imprisoned the Friars from the Požega friary while the guardian of the friary was hung from a stake. (Kemura 1909, 559-567) It is clear that betrayal of the state and cooperation with the enemy caused the loss of all rights and severe punishments.

In its largest range, Bosna Argentina - with different administrative borders - stretched beyond Budim in the north, the Adriatic in the south, the Reliquiae reliquiarum borders in the west, and Belgrade, Bulgaria, Wallachia and Moldova in the east. This vast and unique geographic spread during the Ottoman administration was made possible by the Croatian Franciscans and their rather mobile organization with local, provincial and international significance. But in the mid- $17^{\text {th }}$ century, tensions arose in Bosna Argentina due to its historical heritage and the attachment of its inhabitants to the regional affiliation. A movement aiming at establishing a proper Slavonian province and an independent Slavonic diocese was started among Slavic Franciscans, under the leadership of Marin Ibrisimović. The affiliation with the bishops of Zagreb followed shortly, and Bishop Petar Petretić appointed Fr. Petar Nikolić as his Vicar for Slavonia in 1658. (Moačanin 1997, 35-37; Hoško 2001, 1-23) Tensions, on the other hand, continued to increase in relations between Dalmatian and Bosnian Franciscans, which later led to the inevitable partition of the Province.

\subsection{Franciscans in Slavonia, the Danube Region and Ottoman Hungary}

After the Ottomans won over the territory of Bosna Argentina, the Franciscans retained the right to their church activities under Ottoman rule. This was the reason why they crossed the Sava River from the Bosnian 
side for the second time, and acted pastorally in Slavonia and the Danube region, faced with difficulties common for the Catholics in the area in the mid- $16^{\text {th }}$ century. At that time, Calvinism began to spread rapidly in that region, so in 1551, its propagator Mihajlo Starin reported to Nikola Tuknai that in the seven years of his missionary work in Slavonia, Srijem and on the other side of the Danube, he established 120 Calvinist parishes and held two synods, one in Vukovar and one in Valpovo. (Jambrek 2013, 171179) Islam embraced a large number of former Catholics. About 40,000 Catholics converted to Islam in the vicinity of Brod and Požega, and about as many in eastern Srem. And that's not all. In Srijem, ten Catholic villages converted to Orthodoxy, and the area lost its old Catholic population. (Buturac 1970, 54-56) There is no doubt that one of the main reasons for abandoning Catholicism during this period, and even later, was the apparent shortage of native clergy in the entire area of Turkish rule, including Slavonia and Srijem. In 1581, the Croatian Catholics in Pécs wanted the pastoral care of Bosnian Bishop Fr. Antun Matković and asked him to send them a priest who would use the lingua slavonica. As he did not respond to this request, they asked again for a priest who spoke the Croatian language three years later. In August 1581, Slavonian Catholics organized a synod in Bajinci, not far from Ilok, and sent a letter to Pope Gregory XIII, pointing out: »In this area, which the enemy of Christ and your Church has conquered, we are left as a little light, shining in the thickest darkness, and almost obliterated by our past and heresy, born unbelievably and grown into a hellish and gehennal harvest, so perhaps we have fallen into some misconceptions with such ungodliness and confusion, because the shepherd or visitor never visits us as his own, as sheep that wander without their shepherd, but not stubbornly[.] « (Tóth 2005, 17-21) A church historian Josip Buturac writes that the priests of Srem held a meeting with the bishop of Bosnia in 1591 and that there were about 35 priests in Slavonia and Srijem in that time, 20 of whom belonged to the secular clergy, and 15 were Franciscans. Even in the area surrounding the border, which was under the Christian rule, the situation was not much better, for in 1610, the bishop of Zagreb, Simon Bratulić, mentioned that his diocese was suffering from a shortage of clergy. $(1970,169)$

In Slavonia, at the end of the $16^{\text {th }}$ century, they were attached to the friary in Velika as their pastoral source. It was founded probably by the Franciscans of Požega, who left the town of Požega in 1575. At the beginning 
of the $17^{\text {th }}$ century, around 1620 , the Franciscans established their second centre in the friary in Našice, Slavonia. ${ }^{2}$ They faced great difficulties in the first half of the $17^{\text {th }}$ century. In their letters to Roman Propaganda in 1633, the Catholic merchants of Sarajevo, Banja Luka and Požega nominated Fr. Jerolim Lučić, the guardian of Našice, for the service of bishop, due to his distinguished piety, religious life and pastoral work, notably in Slavonia, where "he was practically the first to sow the seeds of the Catholic faith, especially in Našice, now abiding to the law of Christ in the greatest way [...] He was stoned twice, first by the Donatists for his love of the holy faith, and then by the 'Šokci' (indigenous Croatian Catholic population of Slavonia and Vojvodina) for unity of the calendar." (Fermendžin 1892, 532) Non-Catholics, Calvinists or Orthodox Christians should be recognized under the name »Donatists«, while "Šokci« most likely refers to those who did not want to accept the new calendar, a Gregorian calendar introduced by Pope Gregory XIII in 1581.

The pastoral activities of the Franciscans in Slavonia and the Danube region also made it difficult to appoint bishops in the territory of the former kingdoms of Bosnia, Croatia and Hungary, ruled by the Ottomans. The two centres of ecclesiastical power and responsibility claimed the right to appoint bishops in the area which they could not access: the royal-imperial authority in Vienna and the ecclesiastical authority in Rome. Their positions were almost always substantially different. Referring to the patronage of the Hungarian kings in Vienna (the capital of Habsburg's) as Hungarian and Croatian kings, and Bratislava (then Pozsony) as the capital of Hungarian government in the $16^{\text {th }}$ and $17^{\text {th }}$ centuries, Vienna appointed bishops in areas of Hungary and Croatia that were under Ottoman rule, and even in the Bosnian diocese, in which Habsburgs didn't have such historical rights or authority. On the other hand, the Holy See appointed bishops with other titles and assigned them the authority and responsibility over that area. Realistically, however, the area of responsibility of bishops appointed in Rome was limited by the borders of Bosna Argentina. (Buturac 1970, 69-96) It was clear to the ecclesiastical authorities in Rome that in the area of the former Bosnian and Croat-Hungarian kingdoms, the

2 Archives of the Franciscan Friary in Našice (hereinafter: AFFN), Protocollum antiqui conventus Divi Antonii thaumaturgi Nassicis, volumes 1, 1-2. 
Franciscan Province of Bosna Argentina was the only realistically effective pastoral factor. That is why Rome accepted Bosna Argentina and its members' pastoral activities as the basis of church activity and hierarchical organization on the territory that was under Turkish rule, clearly stating in its documents that the Franciscans were the only relevant pastoral factor in the area and accepting Bosna Argentina and its members' pastoral activities as a basis for organizing church administration. (Molnár 2019, 27-29) Of course, these two forums, one in Rome and the other in Vienna or Pozun, did not give up their positions even in the $17^{\text {th }}$ century, so the concrete church administration in the areas under Turkish rule happened in accordance with the prevailing legal or realistic principle of organizing church administration, or in accordance with their compromise.

In the northern part of Hungary that was under Ottoman rule, in Bačka and Požega, which belonged to the Diocese of Pécs, Catholic missionaries were faced with a different situation when attempting to inspect Catholic religiosity and church infrastructure. In that area, prior to the fall of the medieval Hungarian kingdom, there was a complex network of parishes that disappeared in the $16^{\text {th }}$ century as a result of the Ottoman conquests. The Ottoman occupation caused the disappearance of $65 \%$ of church infrastructure in the Diocese of Pécs by mid- $16^{\text {th }}$ century (Belaj 2001, 26), a tendency that continued in the following years. In 1546, 76 members of the clergy lived in Sanjak of Budim, and thirteen years later, there were only nine of them. Furthermore, only one out of sixteen villages had a priest. In 1607, two Benedictines from Dubrovnik, Antun (Antonio) Velislavi and Ignazio Allegretti, wrote a letter to the Congregation of the Holy Office stating that "most churches are roofless. There are no altars, bells, statues of saints not holy-water vessels, and priests perform baptisms in houses or fields." (Lopašić 1902, 3-4; Molnár 2019, 35) The Bosnian Franciscans, who were responsible for the pastoral care of migrant populations from the south, succeeded in partially replacing the Catholic hierarchy. In the $16^{\text {th }}$ century they occupied the emptied parishes of Srem, Bačka and Požega. The Bosnian Franciscans contributed to the spread of syncretism, well known in Bosnia, but due to the obvious differences in language, jurisdiction and attitude towards the Ottoman conquerors, the Hungarians did not accept them as their spiritual leaders, but largely accepted Calvinism. 


\subsection{Islamization and/or Transition to Orthodoxy}

The process of Islamization was carried out in the areas conquered by the Ottomans, most notably in the area covering the Sanjak of Bosnia. According to the tax register of 1520, the number of Muslims in the Sanjak of Bosnia exceeded $45 \%$ of the total population, while the tax register of 1624 tells us that about 150,000 Catholics, about 75,000 Orthodox and even 450,000 Muslims lived in Bosnia. (Džaja 1999, 69; 1984, 267-292; Buturac 1970, 25-56) Thus, the main process of Islamization took about 150 years, and was very successful. For the sake of successful Islamization, this Sanjak enjoyed a privileged status during the rule of the Ottoman Empire, especially when compared to any other area within its territory on the Balkan Peninsula. The feudal lords not only retained their estate, but also had the rights to inherit them, while, as we shall see later, the native Muslims in Bosnia, over time, completely took over local authority. That definitely was not the case in other countries that were part of the Ottoman Empire, but then again, their nobility probably did not belong to the appropriate religion. (Malcolm 2011, 121-148)

The ruling class was Muslim, and the conversion process of the ordinary people was slowly taking place in all the territories they had conquered. The reasons for the change of faith were many: lower taxes for Muslims; retaining and obtaining estate; avoiding blood tolls; avoiding retaliation; opportunism because it suited them more (just as people today change their political affiliations depending on who is in power); defiance; revenge; avoidance of punishment; adverse economic conditions; because they had "a knife on their neck", that is, because of physical coercion. While the conversion to Islam was encouraged, those who wanted to return to Christianity were punished with death. (Fermendžin 1889, 34; Draganović 1983, 33-79; Mandić 1982, 197; Pandžić 2001, 21)

The previously mentioned tax registers reveal yet another process - the spread of Orthodoxy across Bosnia and Herzegovina. In the medieval state of Bosnia, Orthodoxy was spread among the Christians, but with no results. Apart from a few Orthodox in a small part of south-eastern Bosnia, Orthodoxy in medieval Bosnia was an extremely negligible phenomenon. (Mandić 1982, 159; Škegro 2002, 188) However, as Bosnia joined the Ottoman Empire, there was a significant increase in the number 
of Orthodox in Bosnia, for the first time in that area, due to the fact that the Ottoman Empire had a more favourable attitude towards them, in comparison to the Catholic population, primarily because the Ottomans had a say in the choice of high Orthodox clergy, not to mention that the centre of the Orthodox Church was in the Ottoman Empire (Patriarchate of Peć, Constantinople and Athos) (Molnár 2019, 157-161; Benić 2003, 207-216; Lastrić 1786, 91-92; Buturac 1970, 192-198; Draganović 1934, 11). On the other hand, the Ottoman Empire was constantly at war with a large number of Catholic countries, so Catholics preferred to convert to Orthodoxy over Islam; in other words, they joined the only Christian clergy allowed to operate in the area. In addition, the Orthodox clergy later received privileged status, so they sought to impose themselves on Catholics in the Ottoman Empire.

The Vienna War (1683-1699), that is, the War of the Holy League against the Ottomans, which took place after the unsuccessful siege of Vienna, resulted not only in the end of the Franciscan expansion and abandonment of new territories, but also in the withdrawal of the Franciscans from Bosnia. Fearing Ottoman retribution, many Franciscans abandoned their homes together with other people and moved to the Venetian and Habsburg territories in Dalmatia, Croatia and Slavonia, though some of them became actively involved in the fight against the Ottomans.

\section{Conclusion}

In the territory that was under the Ottoman rule, the Franciscans received a charter, known as Ahidnâme, from Sultan Mehmed II by which he guaranteed them personal inviolability and freedom of religious activity, while the Catholic population was given the right to own property and freedom to reside in that region. Despite these legal guarantees, the position of Christians and Franciscans was fairly difficult. During the Ottoman rule, they suffered bloodshed and exile together with the people, and the Ottomans destroyed their churches and friaries. In 1473, Pope Sixtus IV already mentioned a report by the Bosnian Franciscans according to which the Turks had burned and destroyed almost all Franciscan friaries in Bosnia. The Franciscans, however, remained the only Catholic priests under the Ottoman rule, which was expanding to Central Europe up until 
the end of the $17^{\text {th }}$ century. In these dire conditions, they often hid their identities, moving around in mundane clothes, armed and on horseback. Emerik Pavić, a historian of the Croatian Franciscans in the $18^{\text {th }}$ century, attributes the following phrase: Wherever the Turks and their hordes go, friars with bags follow. And it is certainly true. The expansion of the Islamic Empire encouraged the Franciscans to go to all parts of Croatia that were under the Ottoman rule, to Hungary and Erdelj, the province of the present-day Romania, relying on Ahidnâme. They were organized into the Franciscan province of Bosna Argentina, which in 1591 had sixteen friaries with 163 members on the vast area from the Adriatic to the Carpathians, while one more friary was reported even in Budim in 1623. In the first half of the $17^{\text {th }}$ century, it managed 101 parishes and provided pastoral care for approximately 250 to 300,000 Catholics. Despite the harsh circumstances in which they operated until the mid- $19^{\text {th }}$ century, the Franciscans were able to overcome the Sharia law restrictions and other restrictive regulations thanks to their persistence, perseverance, and surprising resourcefulness. In terms of contemporary standards of human rights, the Ottoman legal framework, based largely on restrictive provisions of the Sharia law, was undoubtedly discriminatory against non-Muslims. However, in the pre-modern world, where general intolerance of minorities was rather common, the Ottoman concept represented, if nothing else, at least the basis for the survival and preservation of a fundamental individual identity. In reality, resourceful and wise Franciscans often managed to stretch this somewhat narrow framework and at least partially fulfil the vital needs of their community. 


\section{References}

Belaj, Vitomir. 2001. Vikarijat zagrebačkog biskupa u Slavoniji i fra Luka Ibrišimović. In: Filip Potrebica, ed. Fra Luka Ibrišimović i njegovo doba, 25-34. Jastrebarsko: Naklada Slap.

Benić, Bono. 2003. Ljetopis sutješkoga samostana. Sarajevo-Zagreb: Synopsis.

LegM [LM], Bonaventura. 1995. Legenda Maior S. Francisci. In: Stefano Bufani, Enrico Menestò, ed. Fontes Franciscani, \$\$1020-1255. Assisi: Porziuncola.

Bullarium Franciscanum, vol. VII. 1904. Conrad Eubel, ed. Romae: Typs Sacrae Congregationis de Propaganda Fide.

Buturac, Josip. 1970. Katolička Crkva u Slavoniji za turskoga vladanja. Zagreb: Kršćanska sadašnjost.

CAss [CA], Compilatio Assisiensis. 1995. In: Stefano Bufani, Enrico Menestò, ed. Fontes Franciscani, \$\$ 1544-1676. Assisi: Porziuncola.

1Cel, Celano, Thoma. 1995. Vita prima S. Francisci. In: Stefano Bufani, Enrico Menestò, ed. Fontes Franciscani, \$\$315-517. Assisi: Porziuncola.

- - -. 1995. Vita secunda S. Francisci. In: Stefano Bufani, Enrico Menestò, ed. Fontes Franciscani, \$\$578-820. Assisi: Porziuncola.

Draganović, Krunoslav. 1883. Izvješće apostolskog vizitatora Petra Masarecchia o prilikama katoličkog naroda u Bugarskoj, Srbiji, Srijemu, Slavoniji i Bosni g. 1623. i 1624. Starine JAZU 39: $1-48$.

- - -. 1934. Izvješće fra Tome Ivkovića, biskupa skradinskog iz godine 1630 . Croatia Sacra 7: 65-78.

- - -. 1983. Biskup Lučić i njegovo doba. Povijesne prilike. Croatica Christiana Periodica 7 (11): 33-79.

Džaja, Srećko Matko. 1999. Konfesionalnost i nacionalnost Bosne i Hercegovine. Mostar.

- - -. 1983. Der bosniche Konfessionalismus. Ein Phänomen der weltgeschitlichen Peripherie. Saeculum 45: 267-292.
Dujčev, Ivan. 1935. Il cattolicesimo in Bulgaria nel secolo XVII secondo i processi istruttori sulla no ina dei vescovi cattolici. Roma: Edizioni Orientalia Christiana.

Esser, Kajetan. 1988. Početak i svrha Franjevačkog reda. Split: Kačić.

Eubel, Conrad, ed. Provinciale Ordinis Fratrum Minorum Vetustissimum. 1898. In: Bullarium Franciscanum V. Romae: Typs Sacrae Congregationis de Propaganda Fide.

Fabianich, Donato. 1884. Firmani inediti dei sultani di Constantinopoli ai conventi francescani e alle autorità civili di Bosnia e di Herzegovina. Firenze: Tip. di M. Ricci.

Fedalto, Giorgio. 2008. Bulgaria e Serbia sotto il Turco: il diverso destino ecclesiastico e culturale. In: Luciano Vaccaro, ed. Storia religiosa di Serbia e Bulgaria, 201-215. Milano: Centro Ambroasiano.

Fermendžin, Eusebius, 1889. Chronicon observantis provinciae Bosnae Argentinae ordinis s. Francisci Seraphici. Zagrabiae: Academia scientarum et artium Slavorum meridionalium.

- - -. 1892. Acta Bosnae potissimum ecclesiastica cum insertis editorum documentorum regestis ab anno 925 usque ad annum 1752. Zagrabiae: Academia scientarum et artium Slavorum meridionalium.

Franzen, August. 1983. Pregled povijesti Crkve. Zagreb: Kršćanska sadašnjost.

Francisci Assisiensis. 1995. Regula non bullata. In: Stefano Bufani, Enrico Menestò, ed. Fontes Franciscani, $\$ ₫ 1-73$. Assisi: Porziuncola

- - -. 1995. Regula bullata. In: Stefano Bufani, Enrico Menestò, ed. Fontes Franciscani, \$\$73a-109a. Assisi: Porziuncola.

Gavran, Ignacije. 2007. Suputnici bosanske povijesti. Sedam stoljeća djelovanja bosanskih farenjavca. Sarajevo - Zagreb: Svjetlo riječi. 
Gonzagae, Francisci. 1578. De origine Seraphicae Religionis Franciscanae. Venetiis: Basae.

Hammer, Joseph von. 1977. Historija Turskoga/Osmanskog/Carstva 1. Zagreb: Nerkez Smailagić.

Hitti, Philip K. 1988. Istorija Arapa od najstarijih vremena do danas. Sarajevo: Veselin Maselaša.

Hourani, Albert. 2010. Islam in European Tought. Cambridge: Cambridge University Press.

Hoško, Franjo Emanuel. 2000. Franjevci u kontinentalnoj Hrvatskoj kroz stoljeća. Zagreb: Kršćanska sadašnjost.

- - -. 2001. Luka Ibrišimović i sukobi među slavonskim i bosanskim franjevcima Bosne Srebrene. In: Filip Potrebica, ed. Fra Luka Ibrišimović i njegovo doba, 1-23. Jastrebarsko: Naklada Slap.

Jambrek, Stanko. 2013. Reformacija u hrvatskim zemljama u europskom konte$k s t u$. Zagreb: Srednja Europa, Biblijski institut.

Jerković, Marko. 2019. Vita activa Franjevaca: Idejna i normativna pozadina djelovanja među Saracenima četvorice jeruzalemskih mučenika. In: Daniel Patafta, Nedjeljka Valerija Kovač, ed. Sv. Nikola Tavelić - njegovo vrijeme i trajna poruka, 185-207. Zagreb: Katolički bogoslovni fakultet Sveučilišta u Zagrebu, Hrvatska franjevačka provincija sv. Ćirila i Metoda, Hrvatska franjevačka provincija sv. Jeronima franjevaca konventualaca.

Jelenić, Julijan. 1918. Spomenici kulturnog rada bosanskih Franjevaca (1437.1878.). Starine Jugoslavenske akademije znanosti i umjetnosti 36: 81-162.

Kemura, Safet. 1902. Turski dokumenti za povijest bosanskih katolika iz sidžila kutubhane Careve džamije u Sarajevu. Glasnik Zemaljskog muzeja u Sarajevu 21: 559-576.

- - -. 1916. Bilješke iz prošlosti bosanskih katolika i njihovih bogomolja po turskim dokumentima. Sarajevo: Islamska dionička štamparija.

Kursar, Vjeran. 2003. Srednjovjekovne percepcije islama. Povijesni prilozi 24: 133-148.
- - -. 2013. Bosna i Hercegovina. In: Lovorka Čoralić, ed. U potrazi za mirom i blagostanjem. Hrvatske zemlje u 18. stoljeću, 389-401. Zagreb: Matica Hrvatska.

Lastrić, Filip. 1786. Philipus ab Occhievia, Epitome vetustatum Bosnensis provinciae. Anconae.

Lopašić, Radoslav. 1902. Slavonski spomenici za XVII. viek. In: Starine JAZU XXX, 2-18. Zagreb: Jugoslavenska akademija znanosti i umjetnosti.

Malcolm, Noel. 2011. Bosna. Kratka povijest. Sarajevo.

Mandić, Dominik. 1968. Franjevačka Bosna. Roma.

- - -. 1982. Etnička povijest Bosne $i$ Hercegovine. Toronto-Zürich-RomaChicago: Ziral.

Marković, Luka. 1995. Polemika ili dijalog s islamom. Arapi i islam u srednjovjekovnim i pijetističkim polemičkim spisima. Livno: Svjetlo Riječi.

Melville, Gert. 2016. The World of Medieval Monasticism - Its History and Forms of Life. Collegeville Minnesota: The Catholic University of America Press.

Moačanin. Nenad. 1997. Požega i požeština u sklopu Osmanlijskog carstva (1537.1691.). Jastrebarsko: Naklada Slap.

Mólnar, Antal. 2019. Confessionalizatin of the Frontier. The Balkan Catholics between Roman reform and Ottoman Reality. Roma: Edizione Cartacea.

Pandžić, Bazilije S. 2001. Hercegovački franjevci. Mostar: Ziral.

Patafta, Daniel. 2018. Franjevačko 13. stoljeće - povijest, teologija, duhovnost. Zagreb: Kršćanska sadašnjost.

Pavich, Emericus. 1766. Ramus viridantis olivae, in arcam militantis ecclesiae relatus, seu paraphrastica, et topographica descriptio provinciae nuper Bosnae Argentinae, jam vero $S$. Joannis a Capistrano nuncupatae. Budae: Typs Leopoldi Francisci Landerer.

Rodinson, Maxime. 2002. Europe and Mistique of Islam. London: I. B. Tauris.

Schacht, Joseph. 1986. Aman. In: Encyclopedia of Islam 1, 429-430. Leiden: Brill. 
Škegro, Ante. 2002. Na rubu opstanka. Duvanjska biskupija od utemeljenja do uključenja u bosanski apostolski vikarijat. Zagreb: Hrvatski institut za povijest.

Tocanel, Pietro. 1972. Laboriosa organizzazione delle missioni in Bulgaria, Moldavia, Valacchia e Transilvania. In: Sacre Congregationis de Propaganda fide memoria rerum $1 / 2$. RomaFrieburg-Wien: Herder.

Tóth, István György. 2005. Franjevci Bosne Srwbrwnw u osmanskoj Mađarskoj i Transilvaniji od 16. do 18. stoljeća. Bosna Franciscana 13(22): 16-41.
De Vitry, Jacobus. 1995. Historia Iherosolimitana Abreviata. In: Stefano Bufani, Enrico Menestò, ed. Fontes Franciscani, \\$2210-2213. Assisi: Porziuncola.

Vladimirović, Luka. 1775. Norinije Starogradjanin Neretvanski, Pripisagnie pocetaka kraglievstva bosanskoga. Venetiis: Ioannes Bassanese.

Waddingus, Luca. 1932. Annales Minorum IX. Ad Claras Aquas (Quaracchi).

- - -. 1933. Annales Minorum XV. Ad Claras Aquas (Quaracchi).

Zirojević, Olga. 1980. Oko naziva Frenk i Latin. Prilozi za orijentalnu filologiju 28-29: 375-385. 